\title{
NUMERICKÁ ANALÝZA RÁZOVO ZAŤǍ̌ENEJ BETÓNOVEJ DOSKY S BFRP VÝSTUŽOU
}

\author{
NUMERICAL ANALYSIS OF BFRP REINFORCED CONCRETE SLAB \\ EXPOSED TO IMPACT LOADS
}

\author{
Daniel Jindra ${ }^{*}, 1$, Petr Hradil ${ }^{1}$ \\ *jindra.d@fce.vutbr.cz \\ ${ }^{1}$ Faculty of Civil Engineering, Brno University of Technology, Veveři 331/95, 60200 Brno, Czech Republic
}

\begin{abstract}
Abstrakt
Článok popisuje numerickú analýzu s využitím MKP jednoducho uloženej betónovej dosky zat’aženej rázovou vlnou od blízkeho výbuchu TNT nálože. Prúty výstuže dosky obsahujú bazaltové vlákna. Je vytvorený $3 \mathrm{D}$ numerický konečnoprvkový model a na analýzu je použitý software s explicitným riešičom. Na účely modelovania účinkov rázového zat’aženia od tlakovej vlny je použitá zjednodušená metóda. Sú porovnané viaceré prípady s rôznymi vel'kost'ami siete, formuláciou konečných prvkov. Výsledky sú porovnávané s experimentálnymi dátami.
\end{abstract}

\section{Kl'účové slová}

Rázové zat’aženie, betónová konštrukcia, numerická analýza, MKP model, výstuž z bazaltových vláken

\begin{abstract}
This paper describes numerical analysis utilizing the FEM of a simply supported concrete slab exposed to close range explosion of TNT charge. Reinforcing bars are made of basalt fibre reinforced plastic (BFRP). 3D numerical model has been created, and a software with explicit solver has been used in order to conduct analyses. A simplified method of the blast loading modelling has been utilized. Several cases with different mesh size or finite element formulation are considered. The results are compared with experimental data.
\end{abstract}

Key words

Impact loading, concrete structure, numerical analysis, finite element model, basalt fibre plastic reinforcement

\section{INTRODUCTION}

Structures are required to retain its resistance also under severe loading conditions, while exposed to extreme loads, e.g. impacts of various objects. For example air plane crash modelled by Králik [1], or impacts of projectiles (defense structures for military purposes). Structures are also required to withstand severe damage caused by pressure wave after explosion (different chemical explosives or gas explosion in civil structures). Several different approaches in modelling the effects of blast load are available in order to numerically analyze the response of exposed structures.

In this study, a so called simplified approach has been adopted. The effect of the blast wave is considered as a time dependent pressure load applied at the exposed structure surface. This approach has been also implemented in LS-Dyna [2], where it is described as "load blast enhanced" (LBE).

Another approach is Arbitrary Lagrangian Eulerian formulation (ALE), where the air domain surrounding the structure and the explosive material itself are included in the background multi material ALE mesh (MMALE) [2]. Blast pressure wave propagation is being modelled. Exposed structure is modelled by Lagrangian elements. Additionally, a fluid structure interaction needs to be established [2], in order to provide a constrain between ALE and Lagrangian meshes.

Coupling of the previous two approaches (LBE and ALE) exist. In this variant, the ALE mesh is established only in the closest structure surrounding. The exterior surface of the air domain which faces the blast (a layer of ambient elements [2]) is loaded by the empirical time dependent pressure function. The purpose of these ambient air elements in this edge layer is to convert the load pressure data into a thermodynamic state data, which are subsequently applied to the surrounding ALE air domain as a source. Density and particle velocity are obtained 
from Rankine-Hugoniot relations [3]. Several comparative studies have been conducted, e.g. by Tabatabaei et al. [4], or Slavik [5], who compared mentioned methods.

The blast itself could be modelled using a smooth particle hydrodynamics (SPH) method, which was presented by Monaghan and Lucy independently in 1977 [6] [7]. This method has been utilized in large variety of tasks, e.g. by Schwer et al [8] or Trajkovski [9], who modelled air blasts and compared SPH to previous methods.

Several concrete structures exposed to blast loading have been modelled, e,g, by Tai et al. [10]; Zhao and Chen [11], [12], Thiagarajan et al. [13]; Dubec, Maňas, Stoller and Stonis [14]. In this study however, a numerical analysis of one of the physical experiments conducted by Feng et al. [15], who experimentally investigated the response of one-way concrete slab reinforced by basalt fibre reinforced plastic (BFRP) under close-in TNT explosion, has been conducted. For concrete, the nonlinear material model proposed by Schwer and Murray [16] has been utilized. The parameter values of this model are based on the calibration study by Jiang and Zhao [17].

\section{Physical model and experimental result of the concrete slab}

The physical experiments are well described in the study by Feng et al. [15]. In this study, a variant of concrete slab noted as "B1-1" [15] is investigated. The concrete class of the slab is C40, with the average strength of concrete cubes cured for 150 days equal to $46.9 \mathrm{MPa}$ [15]. The slab dimensions are: $1100 \mathrm{~mm}$ in length, $1000 \mathrm{~mm}$ in width, and $40 \mathrm{~mm}$ in height. Spacing (axial distance) of the BFRP bars is $50 \mathrm{~mm}$ in both directions, diameter is equal to $\varnothing 6 \mathrm{~mm}$. Concrete cover is equal to $5 \mathrm{~mm}$, the effective depth of the slab is $32 \mathrm{~mm}$.

The BFRP bars have been tested in order to establish the material properties [15]. The average tensile strength of $1.53 \mathrm{GPa}$, and the average elastic modulus of $57.68 \mathrm{GPa}$ have been utilized as material values in this study. The shape of the TNT mass $(200 \mathrm{~g})$ is rectangular prism, located in the distance of $400 \mathrm{~mm}$ above the mid span of the slab upper surface. The slab is simply supported on a steel frame, with a structural span of $1000 \mathrm{~mm}$. Strain gauges were pre-pasted onto the BFRP bars surface, two at the mid-span and two at the quarter span of the slab, as indicated in the Fig. 1. The history of the axial strain of the BFRP bar (along the direction of the structural span) in the mid-span of the slab is depicted in the Fig. 1.
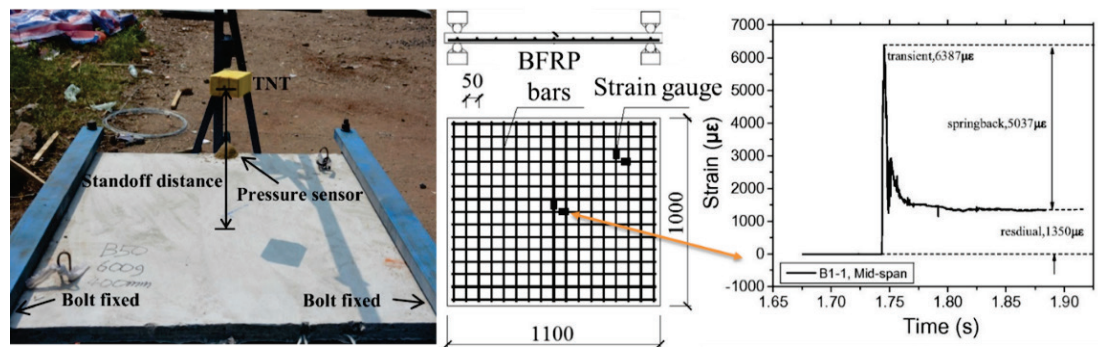

Fig. 1 Experimental set-up and the mid-span strain history of the BFRP bar [15].

\section{NUMERICAL ANALYSES}

\section{Blast loading modelling approach - Simplified Blast Model (LBE)}

A simplified blast model with a pure Lagrangian approach of FEM is used in order to model the effect of a blast wave. The wave effect is considered as a time dependent pressure load, which is applied at the upper surface of the concrete slab, described as "load blast enhanced" (LBE) (LS-Dyna) [2]. It is based on the empirical blast loading function established by Randers-Pehrson and Bannister [18] defined as:

$$
P(t)=P_{r}(t) \cos ^{2} \theta+P_{s}(t)\left(1+\cos ^{2} \theta-2 \cos \theta\right),
$$

where $\theta$ is the angle of incidence, $P_{\mathrm{r}}(t)$ and $P_{\mathrm{s}}(t)$ are time dependent reflected and incident overpressures respectively, both defined by Friedlander [19] equation. In case of $P_{\mathrm{s}}(t)$ the function is defined as:

$$
P_{S}(t)=P_{S o}\left(1-\frac{t}{t_{o}}\right) \cdot e^{-b \frac{t}{t_{o}}}
$$

where $P_{\text {so }}$ is the peak incident overpressure, $b$ is a decay coefficient of the waveform, and $t_{\mathrm{o}}$ is the positive phase duration. These parameters are defined in dependence on scaled distance $Z$ introduced by Hopkinson [20] and Cranz [21]: 


$$
Z=\frac{R}{W^{1 / 3}},
$$

where $R$ is the distance from the center of blast, and $W$ is the equivalent TNT mass. Parameter values in SI units are obtained from JRC report [22]. In this paper, the TNT mass is $200 \mathrm{~g}$, located $400 \mathrm{~mm}$ above the upper surface mid span. The scaled distance $Z$ is hence equal to $0.684 \mathrm{~m} \cdot \mathrm{kg}^{-1 / 3}$. The arrival time of the blast wave $t_{\mathrm{a}}$ is approximately $155 \mu \mathrm{s}$.

\section{Material model for concrete - Schwer Mirray Cap model}

In order to describe the behavior of the concrete slab, nonlinear material model needs to be utilized. Schwer Murray material model [16] is a material model suitable to analyze concrete structures, which is implemented in LS-Dyna material library [2] (MAT 145). The model is based on a yield surface defined by the function:

$$
Y\left(I_{1}, J_{2}, J_{3}, \kappa\right)=J_{2}-R\left(J_{3}\right)^{2} F_{f}^{2}\left(I_{1}\right) F_{c}\left(I_{1}, \kappa\right),
$$

where $I_{1}$ is the first invariant of the stress tensor. $J_{2}$ and $J_{3}$ are invariants of the deviatoric stress tensor. $R\left(J_{3}\right)$ is the Rubin strength reduction factor and $\kappa$ is the cap hardening parameter. The yield surface consist of two parts: the hardening compaction surface $F_{c}\left(I_{1}, \kappa\right)$, and the shear failure surface $F_{f}\left(I_{1}\right)$ which is defined as:

$$
F_{f}\left(I_{1}\right)=\alpha-\lambda e^{-\beta I_{1}}+\theta I_{1},
$$

where parameters $\alpha, \beta, \lambda$ and $\theta$ are determined by triaxial compression test results. The expression of the hardening compaction surface is defined by equations:

$$
\begin{gathered}
F_{c}\left(I_{1}, \kappa\right)=1-\frac{\left(I_{1}-L(\kappa)\right)^{2}}{(X(\kappa)-L(\kappa))^{2}} \quad \text { for } I_{1}>L(\kappa), \\
F_{c}\left(I_{1}, \kappa\right)=1 \quad \text { for } I_{1} \leq L(\kappa) \\
L(\kappa)=\kappa \text { for } \kappa>\kappa_{0}, \\
L(\kappa)=\kappa_{0} \text { for } \kappa \leq \kappa_{0}, \\
X(\kappa)=L(\kappa)+R F_{f}\left(I_{1}\right),
\end{gathered}
$$

where $R$ is the cap aspect ratio. Hardening compaction surface and the shear failure surface are combined by a multiplicative formulation which allows their continuous and smooth combination at their intersections.

Parameter values utilized for this material model are defined in accordance with the calibration study by Jiang and Zhao [17]. For this process, the uniaxial compression strength of $f_{c m}=46.9 \mathrm{MPa}$ has been considered, which is the average strength of the test specimens as described by Feng et al. [15]. The values are summarized in the Fig. 2 left.
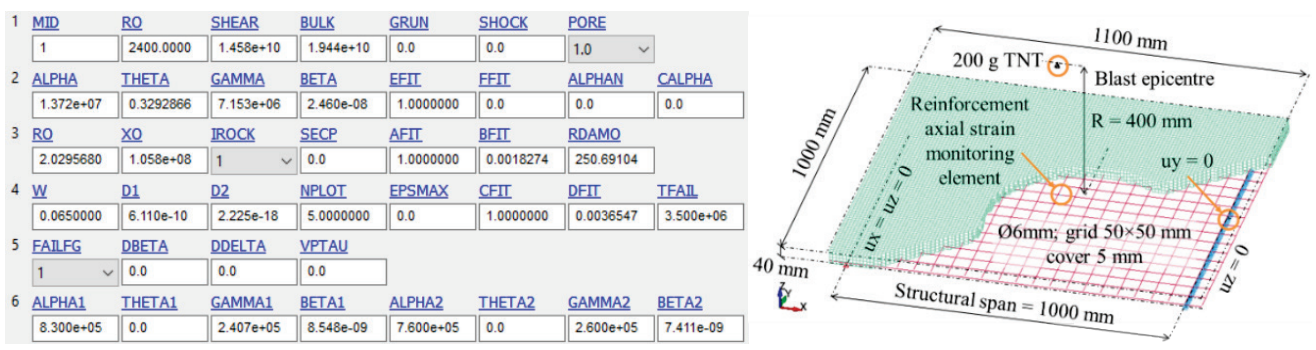

Fig. 2 left: Material input card for MAT 145 (in SI units); right: Numerical model geometry.

\section{Numerical finite element models}

Numerical model geometry is based on the experimental model dimensions, and is depicted in the Fig. 2 right. The geometry of the steel frame supporting the slab is neglected, and simply supported slab is being modelled by utilizing the appropriate boundary conditions. The concrete slab consists of regular hexahedral mesh of solid elements (for $10 \mathrm{~mm}$ mesh in a shape of exact cubes). Reinforcing bars are modelled by beam elements with the 
same mesh size as the solid elements. Two variants of the mesh size are considered, $10 \mathrm{~mm}$ and $8 \mathrm{~mm}$, with the total number of finite elements (solid + beam) equal to 48610 (60 709 nodes) and 92023 (110 901 nodes) respectivelly.

Formulation of the beam elements is considered according to Hughes-Liu with cross section integration in all the cases. However various formulations of solid finite elements are adopted, noted as \#A, \#B and \#C:

- $\quad \# \mathrm{~A}=$ Solid element with constant stress (along with hourglass control) (1)

- $\quad \# B=$ Fully integrated solid intended for poor aspect ratio elements (efficient formulation [2]) $(-1)$

- $\quad \# \mathrm{C}=$ Fully integrated solid [2] (2)

The history of axial strain is being monitored in a reinforcing bar located in the mid-span of the slab, in the direction of the structural span (x direction of the GCS).

Reinforcement material (BFRP) has been considered as bilinear material model with negligible hardening, practically linear elastic and ideal plastic behavior. Material values are based on experimental tests [15], described in the chapter 1 of this study.

\section{ANAL YSES RESULTS}

Figure 3 depicts the first principal strain at the bottom and top surface of the concrete slab in various times of the numerical analysis. History of axial strain of the reinforcement bar in the mid-span (along the structural length of the slab) is plotted in the Fig. 4 for several cases (as described in the previous chapter), along with the measured reference approximation. This reference is obtained graphically from the picture in Fig. 1 right [15].

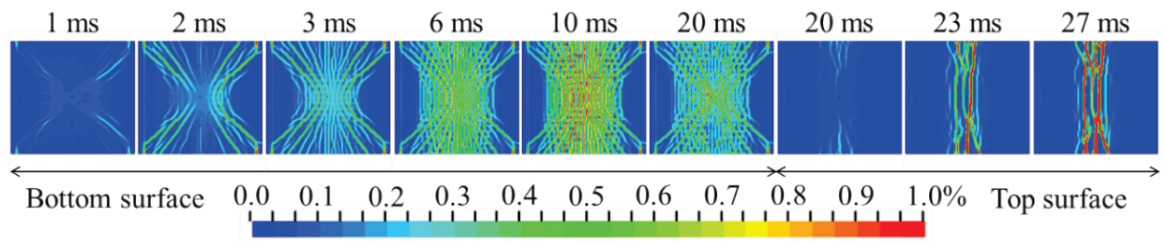

Fig. 3 First principal strain plots at the top and bottom slab surface in various time (\#A, $10 \mathrm{~mm}$ mesh).

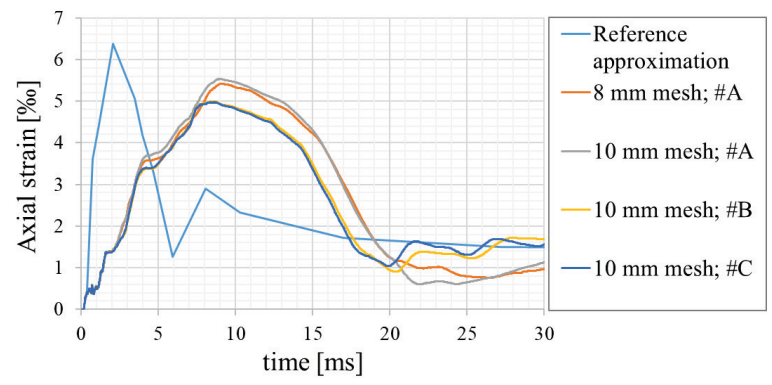

Fig. 4 History of axial strain in the reinforcement bar.

\section{DISCUSSION}

Two mesh sizes have been compared so far, 10 and $8 \mathrm{~mm}$ grid. The difference in the results is rather negligible (Fig. 4). Coarser mesh has not been investigated, as it is assumed, that for $40 \mathrm{~mm}$ thick slab, $10 \mathrm{~mm}$ mesh is already coarse enough. More significant difference in the analysis result is observed, when a different solid element formulations have been adopted. For cases with full integration (\#B and \#C), the maximal axial strain values in the steel bar are $5.0 \%$, whereas for the single point integration (\#A), the peak strain is approx. $5.5 \%$. The initial strain rate (slope of the graph) is slightly smaller than the reference approximation in all the cases (Fig. 4). In order to see this difference more precisely, direct experimental data would be required rather than graphically approximated curve. The axial strain maximums of all the modelled cases (5.0-5.5\%) are in good match with the 
measured peak (6.4\%). It is assumed that in order to obtain better match in strain rate (slope of the strain-time curve), the stiffness of the numerical model is required to be calibrated. It is not expected the finer mesh or a different material models (for concrete) would have significant influence on the initial strain rate [23].

The crack patterns at the bottom surface of the concrete slab have developed in the direction parallel to the supports, and also in diagonal directions (Fig. 5 right). The first principal strain plots (Fig. 3 left part) are of similar patterns. More significant upper surface cracks have evolved in the direction parallel to the slab supports (Fig. 5 left). The same patterns are observed in the first principal strains (Fig. 3 right part), which were caused by the slab oscillations initiated by the dynamic load.
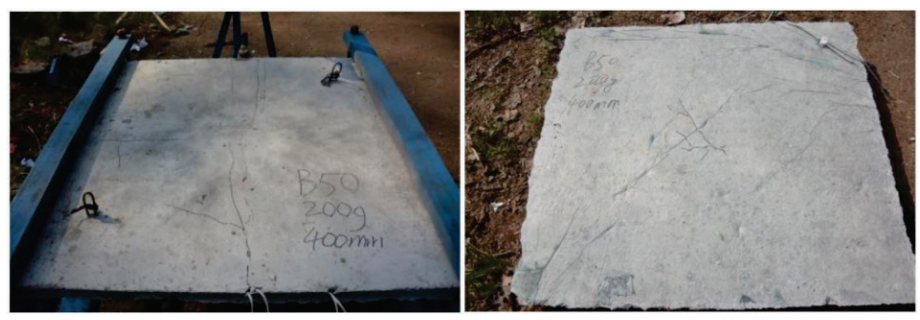

Fig. 5 Damage patterns of the slabs after physical experiment at top surface (left) and bottom surface (right) [15].

The simplified blast model considers the spherical source of the explosion from a single point [2], with the validity range of scaled distance $Z$ in interval $(0.147 ; 40) \mathrm{m} \cdot \mathrm{kg}^{-1 / 3}$. The scaled distance value of the experiment set up is $0.684 \mathrm{~m} \cdot \mathrm{kg}^{-1 / 3}$, therefore within the validity interval of the simplified blast approach. However, the shape of the TNT explosive was not spherical (but rectangular prism), what might cause some additional differences between the experimental and numerical results.

\section{CONCLUSION}

Explicit finite element numerical analyses (FEA) of the simply supported concrete slab reinforced with basalt fiber reinforced plastic (BFRP) have been conducted. The structure is exposed to a pressure wave caused by a close range blast of $200 \mathrm{~g}$ TNT.

Three different formulations of the concrete solid elements, here referred as \#A, \#B and \#C have been considered. The formulations differed in integration point numbers or other modifications.

Two densities of the mesh have been considered, regular $8 \mathrm{~mm}$ and $10 \mathrm{~mm}$ mesh of the concrete solid elements. Finer meshes have not been investigated, due to current license limitations (limited number of finite elements to 125000 ). The difference in the results (crack patterns, axial strain) between $8 \mathrm{~mm}$ and $10 \mathrm{~mm}$ meshes is rather negligible. It is assumed that slightly finer mesh would be more suitable $(5 \mathrm{~mm})$ in order to capture the concrete crack patterns more precisely. This will be tested in the subsequent research when feasible.

Based on the observed axial strain in the reinforcement bar, the results of the numerical analyses and the experimental data are in a nice match considering the maximums of the strain-time curves, with $5.0-5.5 \%$ for numerical analyses and $6.4 \%$ for the experiment. However, the strain rates (slopes of the strain history curves) obtained from the numerical analyses are noticeably smaller than the strain history based on experimental data (Fig. 4). Although the reference strain-time data are based on a graphical approximation of raster figure (Fig. 1), the approximation error is expected to be smaller than this difference.

Performance of a different material model (for concrete) has not yet been examined for this current setting. However, more significant might be to calibrate the structure stiffness (along with boundary condition stiffness), which could be crucial for a proper strain rates. Further investigation is required.

\section{Acknowledgement}

This paper has been created with the financial support of the project FAST-J-21-7169 provided by the Brno University of Technology fund for specific university research.

\section{References}

[1] KRÁLIK, J. (2014). Safety of nuclear power plant against the aircraft attack. Applied Mechanics and Materials, vol. 617, p. 76 - 80. ISSN: 1662-7482. DOI: 10.4028/www.scientific.net/AMM.617.76. 
[2] Livermore Software Technology Corporation (1997), LS-Dyna ${ }^{\circledR}$ Theoretical Manual. Livermore, CA: Livermore Software Technology Corporation.

[3] KINNEY, G. F., K.J. GRAHAM. (1985). Explosive shocks in Air. Springer-Verlag Berlin Heidelberg. Online ISBN: 978-3-642-86682-1, 1985. DOI: 10.1007/978-3-642-86682-1.

[4] TABATABAEI, Z.S., J.S. VOLZ (2012). A comparison between three different blast methods in LSDyna ${ }^{\circledR}:$ LBE, MM-ALE, Coupling of LBE and MM-ALE. Paper presented at the 12th International LS-Dyna ${ }^{\circledR}$ Users Conference, Detroit U.S. 2012.

[5] SLAVIK, T. (2010). A coupling of empirical explosive blast loads to ALE air domains in Ls-Dyna®. Paper presented at the 7th European LS-Dyna ${ }^{\circledR}$ Conference, Salzburg Austria 2009.

[6] GINGOLD R.A., J.J. MONAGHAN. (1977). Smoothed particle hydrodynamics: theory and application to non-spherical stars. Monthly Notices of the Royal Astronomical Society vol. 181, is. 3, p. 375-389, ISSN (online): 1365-2966. DOI: 10.1093/MNRAS/181.3.375.

[7] LUCY L.B. (1977). A numerical approach to the testing of the fission hypothesis. The Astronomical Journal, vol. 82, p. 1013-24. ISSN: 00046256. DOI: 10.1086/112164.

[8] SCHWER, L., T. HAILONG, S. MHAMED. (2015). LS-Dyna Air Blast Techniques: Comparisons with Experiments for Close-in Charges. Paper presented at the 10th European LS-Dyna ${ }^{\circledR}$ Conference, Würzburg Deutschland 2015.

[9] TRAJKOVSKI J. (2017). Comparison of MM-ALE and SPH methods for modelling blast wave reflections of flat and shaped surfaces. Paper presented at the 11th European LS-Dyna ${ }^{\circledR}$ Conference, Salzburg Österreich 2017.

[10] TAI, Y.S., T.L. CHU, H.T. HU and J.Y. WU. (2011). Dynamic response of a reinforced concrete slab subjected to air blast load. Theoretical and Applied Fracture Mechanics. vol. 56, issue. 3, pages.140147. ISSN 0167-8442. DOI: 10.1016/j.tafmec.2011.11.002.

[11] ZHAO, C.F. J.Y. CHEN. (2013). Damage mechanism and mode of square reinforced slab subjected to blast loading. Theoretical and Applied Fracture Mechanics. vol. 63-64, p. 54-62. ISSN 0167-8442. DOI: $10.1016 /$ j.tafmec.2013.03.006.

[12] ZHAO, C.F., J.Y. CHEN, Y. WANG and S.J. LU. (2012). Damage mechanism and response of reinforced concrete containment structure under internal blast loading. Theoretical and Applied Fracture Mechanics. vol. 61, p. 12-20. ISSN 0167-8442. DOI: 10.1016/j.tafmec.2012.08.002.

[13] THIAGARAJAN, G., A.V. KADAMBI, S. ROBERT and C.F. JOHNSON. (2015). Experimental and finite element analysis of doubly reinforced concrete slabs subjected to blast loads. International Journal of Impact Engineering. vol. 75, p. 162-173. ISSN 0734-743X. DOI: 10.1016/j.ijimpeng.2014.07.018.

[14] DUBEC, B., P. MAŇAS, J. ŠTOLLER and P. STONIS. (2019). Experimental and numerical assessment of fibre reinforced concrete slab under blast load, ICMT 2019 - 7th International Conference on Military Technologies, Proceedings 2019. ISBN: 978-172814593-8.

DOI: 10.1109/MILTECHS.2019.8870129.

[15] FENG, J., et al. (2017). Experimental research on blast-resistance of one-way concrete slabs reinforced by BFRP bars under close-in explosion. Engineering Structures, vol. 150 p.550-561. ISSN: 01410296. DOI: 10.1016/j.engstruct.2017.07.074.

[16] SCHWER, L.E., Y.D. MURRAY. (1994). A three invariant smooth cap model with mixed hardening. International Journal for Numerical and Analytical Methods in Geomechanics, vol. 18, pp. 657-688, DOI: $10.1002 /$ nag. 1610181002 .

[17] JIANG, H., J. ZHAO. (2015). Calibration of the continuous surface cap model for concrete, Finite Elements in Analysis and Design. vol. 97, p. 1-19. ISSN 0168-874X. DOI: $10.1016 /$ j.finel.2014.12.002.

[18] RANDERS-PEHRSON, G., and K.A. BANNISTER, (1997). Airblast loading model for DYNA2D and DYNA3D. Army Research Laboratory, Rept. ARL-TR-1310, U.S., 1997.

[19] FRIEDLANDER, F.G. (1946). The diffraction of sound pulses I. Diffraction by a semi-infinite plane. Proceedings of the Royal Society A. 1946. ISSN 0080-5630. DOI: 10.1098/rspa.1946.0046.

[20] HOPKINSON, B., (1915) British Ordnance board minutes 13565, in: The National Archives, Kew, UK, pp.11.

[21] CRANZ, C., (1925) Lehrbuch der Ballistik. Erster Band. AusereBalistik, Springer Verlag, Berlin.

[22] KARLOS, V., G. SOLOMOS, (2013). Calculation of blast loads for application to structural components. JRC Technical Reports, Report EUR 26456 EN, Luxembourg. ISSN 1831-9424. DOI: $10.2788 / 61866$.

[23] JINDRA, D., P. HRADIL, J. KALA, P. KRÁL (2020). Mesh size influence of the concrete slab FE model exposed to impact load for various material models. Transactions of VSB - Technical University of Ostrava, Civil engineering Series, 20(2), 1-7, DOI: 10.35181/tces-2020-0010. 